\title{
The role of social assistance program on management accounting practice
}

\author{
Mira Fajrin Sholichatun, ${ }^{1}$ Hani Werdi Apriyanti ${ }^{2}$ \\ 1,2Universitas Islam Sultan Agung Semarang, Indonesia \\ email: mirafajrin8@gmail.com
}

\begin{abstract}
Purpose - The purpose of this study is to determine the procurement of social assistance program on management accounting practice of MSMEs in food industry sector in Semarang during the Covid-19 pandemic.

Method - The population in this study was 17,602 MSMEs in Semarang. The research samples were 144 MSMEs in the food industry sector in Semarang obtained using a non-random sampling technique with a purposive sampling method. The data were then processed using descriptive analysis, data quality test, classic assumption test, simple regression analysis, and hypothesis test with IBM SPSS 25 software.
\end{abstract}

Result - The results show that procurement of social assistance program affected management accounting practice of MSMEs in the food industry sector in Semarang during the Covid-19 pandemic.

Implication - The results show that with the support provided by the government and financial institutions in the form of social assistance programs to MSMEs had positive impacts by encouraging MSMEs to implement management accounting practices during the covid-19 pandemic.

Originality - Procurement of Social Assistance Program is an independent variable which is later expected to be able to overcome MSME problems due to the financing faced by MSMEs in Semarang in response to the impact of Covid-19 pandemic.

Keywords: social assistance program; management accounting pratice; pandemic affected MSMEs 
Mira Fajrin Sholichatun, Hani Werdi Apriyanti

\section{Introduction}

Micro, Small and Medium Enterprises are one of businesses to reduce the heavy burden faced by the national economy (Helmalia, 2018). Those can be

JIAFR | 294 considered as the backbone of national economy is because MSMEs are the most strategic businesses involving the livelihood of many people (Wicaksono \& Nuvriasari, 2015). Until now, MSMEs are considered as an effective sector to improve economy.

The growth rate of MSMEs is quite fast, higher than the growth of largescale businesses. The number of MSMEs in Indonesia has recently reached 57 million MSMEs which are divided into 3: micro, small, and medium enterprises (Suindari \& Juniariani, 2020). Economic growth can be seen from significant small business activities, both traditional and modern sectors through MSMEs. According to the Ministry of Cooperatives and Small and Medium Enterprises, per 2012, the number of MSMEs in Indonesia has reached 64,194,057 MSMEs. Furthermore, the number of MSMEs in Semarang, the capital city of Central Java province and one of the largest cities, has reached 17,602 MSMEs per September 2020 (Semarang Department of Cooperatives and MSMEs).

At the beginning of 2020, the outbreak of positive Covid-19 cases entered Indonesia. The Covid-19 outbreak has impacted all sectors in Indonesia, including MSMEs. A total of 17,602 MSMEs in Semarang are threatened with the significant income decrease when compared to their commonly obtained income and some even choose to temporarily close their businesses during the Covid-19 pandemic. On the other hand, MSME business actors must also continuously pay their loans, loan interests, and obligations, such as taxes. Thus, MSME business actors desperately need the government's social assistance program, to continuously grow and develop their business during the Covid-19 pandemic.

To deal with the impact of Covid-19 pandemic, the government has made various policies to provide economic stimulus to MSMEs, including Social Assistance Program Policy for MSMEs. The government has provided 
assistance to MSMEs in the form of Social Assistance Program through two government agencies concerned with MSMEs, namely the Ministry of Cooperatives and Small \& Medium Enterprises (known as KemenkopUKM) and Ministry of Industry (known as Kemenperin). These two ministries have developed various strategies to help MSMEs affected by the Covid-19 pandemic, including free from loan payments, tax breaks for 6 months, and cash transfers for micro-scale businesses (Rahma, 2020).

Semarang is a city with a fairly high number of MSMEs in Indonesia performing an innovative business capital assistance program with a fairly light credit assistance of $3 \%$ per year or $0.25 \%$ per month. The social assistance program has existed since 2017 known as "Program Kredit Wirausaha Bangkit Jadi Jawara" (Wibawa). The presence of this program helped MSMEs in Semarang develop through a business capital credit system with a relatively light interest rate and eventually improve the welfare of MSME community through these business capital loans.

To manage social assistance from the Government, MSMEs need to implement management accounting practices. For MSMEs, management accounting practices are needed to manage and develop MSMEs during the Covid-9 pandemic by considering various financial and non-financial information to help MSMEs improve their business in the midst of Covid-19 pandemic. MSME actors must be able to manage, allocate, and utilize financial resources without causing negative impacts. In this case, management accounting practice is appointed to provide a financial information for management purposes related to information for management to make a final decision. The more information obtained to assist MSMEs in making their final decisions, the better their quality (Herliansyah, 2018). With this social assistance, MSMEs will pay more attention and careful in managing their finances, as encouraged to practice the management accounting assisted by the government. MSMEs will be encouraged to well manage finances and perform financial management as material for decision making assisted by the government optimally used by MSMEs. Thus, MSMEs are able to increase competitiveness during the COVID-19 pandemic, improve MSME 
performance and be able to restore and develop MSMEs during the Covid-19 pandemic by implementing the management accounting practices. Based on the above background, the research problem is formulated "Does social assistance program affect management accounting practice in food industry sector during the Covid-19 pandemic?"

\section{Literature Review}

\section{Policy Implementation Theory}

In this study, policy implementation theory was used to explain the relationship between Semarang Government policies in accelerating the handling the Covid-19 impact on MSMEs in Semarang. Thus, MSMEs can pay more attention and careful in managing their finances since obliged to provide reports on funds obtained from Semarang Government. MSMEs are encouraged to well manage finances and perform financial planning as material for making decisions on funds obtained from Semarang Government to be optimally used. Thus, social assistance program for MSMEs possibly increased MSME competitiveness, improved MSME performance, as well as restored and developed MSMEs during the Covid-19 pandemic. Thus, management accounting practices are needed to manage and develop MSMEs during the Covid-19 pandemic by considering various financial information and non-financial information to assist MSMEs in improving their business in the midst of Covid-19 pandemic with the provision of social assistance programs from Semarang Government for SMEs affected by the COVID-19 pandemic.

\section{Contingency Theory}

The reason why the researcher used the contingency theory is because MSMEs are encouraged to develop good and appropriate management accounting practices. The development of management accounting practice is made to develop business and improve MSME financial management encouraged by the social assistance programs provided by the government. The social assistance program can urge MSMEs by requiring 
financial management as a form of responsibility for social assistance funds. With the pressure and conditions triggering the MSMEs to develop business and compete with others by implementing the management accounting practices.

\section{Hypothesis Development}

In this pandemic situation, a fast mechanism is needed. Thus, social assistance for MSMEs as one sector affected by the Covid-19 pandemic. Salle (2019) explained that a "policy in social assistance program introduces many new, innovative, and large-scale approaches". Policies in social assistance program are used to explain the relationship between those issued by Semarang Government in accelerating the handling of Covid-19 impact on an MSMEs in Semarang. Thus, Semarang Government hopes that social assistance provided for MSMEs affected by Covid-19 pandemic can well improve their business and utilize the social assistance in accordance with their business needs. To survive and remain sustainable, MSME needs to use financial information as well as non-financial information. Reid and Smith (2002) in Azudin \& Mansor (2018) stated that "companies can gain access to financial and non-financial information to help improve the operating activities through Management Accounting Practice. This is very important because financial and non-financial information is needed to access its business operating system through the use of management accounting practices". That way, MSMEs can improve their business managerial functions.

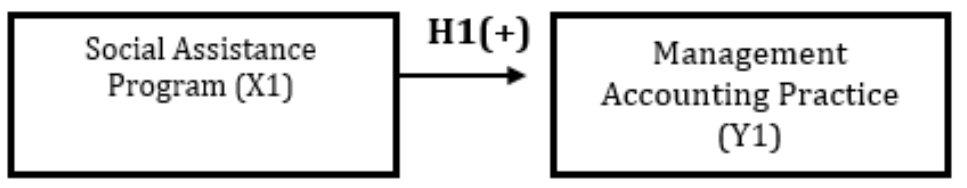

Figure 1. Research Framework 
It can be said that the implementation of policies from Semarang Government in handling the impact of Covid-19 will impact MSMEs encouraged to make decisions. The decision-making is to develop good management accounting practices in MSMEs. In this case, the contingency of the procurement of social assistance programs due to the impact of Covid-19 expecting that MSMEs will be able to develop the management accounting practices to develop businesses and improve MSME financial management encouraged by the social assistance program provided by Semarang Government.

Nanda (2010) in Prihastiwi \& Sholihin (2018) explained that the use of management accounting practices can help SMEs in managing their resources to increase the value given to customers and owners/managers. In this case, the use of management accounting practice is very helpful in managing the company, including in terms of planning and budgeting for decision making. Therefore, with the provision of social assistance programs, MSMEs can properly use and utilize management accounting practices. Based on this description, it can be concluded that social assistance program positively affects management accounting practice. Thus, the first hypothesis of this study is formulated as follows:

\section{$H_{1}$ : Social assistance program positively affects management accounting practice}

\section{Research Methods}

This research used quantitative research with explanatory research approach. The population in this study was all MSME actors in Semarang. The samples were collected using a non-random sampling technique with a purposive sampling method. The minimum sample size in this study was determined using Slovin formula. Thus, 144 SMEs were obtained based on the following criteria: 1) MSMEs operating for at least 3 years. 2) MSMEs still producing in the midst of Covid-19 pandemic. The data were collected through distribution of questionnaires. The questionnaires were distributed through online using google form link sent through WhatsApp. This study 
used hypothesis testing of simple regression analysis as a statistical approach with one independent variable and one dependent variable.

This study used Likert scale ranging 1-5. The Likert scale with the answer characteristic of scale 1 (one) indicates that respondent strongly agrees with the questionnaire, scale 2 (two) indicates that respondent agrees, scale 3 (three) indicates that respondent is neutral or has no opinion, scale 4 (four) indicates that respondent does not agree with the questionnaire, and scale 5 (five) indicates that respondent strongly disagrees with the questionnaire.

Table 1. Variables, Operational Definitions and Dimensions and Indicators

\begin{tabular}{|c|c|c|c|c|}
\hline Variable & $\begin{array}{l}\text { Operational } \\
\text { Definition }\end{array}$ & Dimension & Indicator & Questionnaire \\
\hline \multirow[t]{2}{*}{$\begin{array}{c}\text { Management } \\
\text { Accounting } \\
\text { Practice }\end{array}$} & $\begin{array}{l}\text { The process of } \\
\text { identifying, } \\
\text { measuring, } \\
\text { collecting, } \\
\text { analyzing, preparing } \\
\text { and communicating } \\
\text { financial/financial } \\
\text { information that is } \\
\text { used by } \\
\text { management for } \\
\text { planning, } \\
\text { evaluation, control } \\
\text { within an } \\
\text { organization and to } \\
\text { ensure the } \\
\text { determination of } \\
\text { sources and } \\
\text { accountability for } \\
\text { these sources } \\
\text { (Charles T. } \\
\text { Homgren, } 1993 \text { in } \\
\text { Pusung \& Lumowa } \\
\text { 2015). }\end{array}$ & $\begin{array}{l}\text { Information } \\
\text { System }\end{array}$ & $\begin{array}{l}\text { Financial } \\
\text { planning } \\
\text { (Alleyne \& } \\
\text { Marshall, } \\
2011 \text { in } \\
\text { Prajanto \& } \\
\text { Dian Pratiwi, } \\
\text { 2019) }\end{array}$ & $\begin{array}{l}\text { MSMEs carry out } \\
\text { financial planning } \\
\text { using both manual } \\
\text { and computerized } \\
\text { information } \\
\text { systems. } \\
\text { MSMEs carry out } \\
\text { financial } \\
\text { records/administra } \\
\text { tion, both debts, } \\
\text { receivables, } \\
\text { inventories, and } \\
\text { assets using both } \\
\text { manual and } \\
\text { computerized } \\
\text { information } \\
\text { systems. } \\
\text { MSMEs are able to } \\
\text { make simple } \\
\text { financial budgets } \\
\text { using both manual } \\
\text { and computerized } \\
\text { information } \\
\text { systems. }\end{array}$ \\
\hline & & & $\begin{array}{l}\text { Financial } \\
\text { Report } \\
\text { (Alleyne \& } \\
\text { Marshall, } \\
2011 \text { in } \\
\text { Prajanto \& } \\
\text { Dian Pratiwi } \\
\text { 2019) }\end{array}$ & $\begin{array}{l}\text { MSMEs prepare financial } \\
\text { reports, namely balance } \\
\text { sheets or financial } \\
\text { positions and income } \\
\text { statements using } \\
\text { information systems, } \\
\text { both manual and } \\
\text { computerized. }\end{array}$ \\
\hline
\end{tabular}


Mira Fajrin Sholichatun, Hani Werdi Apriyanti

JIAFR | 300

\begin{tabular}{|c|c|c|c|c|}
\hline & & & $\begin{array}{l}\text { Achievement } \\
\text { evaluation } \\
\text { (Alleyne \& } \\
\text { Marshall, } \\
2011 \text { in } \\
\text { Prajanto \& } \\
\text { Dian Pratiwi } \\
\text { 2019) }\end{array}$ & $\begin{array}{l}\text { MSMEs use } \\
\text { management accounting } \\
\text { information systems to } \\
\text { evaluate performance } \\
\text { achievements, for } \\
\text { example sales targets }\end{array}$ \\
\hline & & & $\begin{array}{l}\text { Decision } \\
\text { making } \\
\text { (Alleyne \& } \\
\text { Marshall, } \\
2011 \text { in } \\
\text { Prajanto \& } \\
\text { Dian Pratiwi } \\
\text { 2019). }\end{array}$ & $\begin{array}{l}\text { 1. MSMEs manage } \\
\text { finances using both } \\
\text { manual and } \\
\text { computerized } \\
\text { information } \\
\text { systems for various } \\
\text { decisions, such as } \\
\text { investment and } \\
\text { funding during the } \\
\text { Covid-19 } \\
\text { pandemic. } \\
\text { MSMEs perform } \\
\text { financial } \\
\text { calculations using } \\
\text { both manual and } \\
\text { computerized } \\
\text { information } \\
\text { systems for the } \\
\text { future after the } \\
\text { Covid-19 } \\
\text { pandemic. }\end{array}$ \\
\hline \multirow[t]{2}{*}{$\begin{array}{l}\text { Procurement } \\
\text { of Social } \\
\text { Assistance } \\
\text { Programs }\end{array}$} & \multirow{2}{*}{$\begin{array}{l}\text { Procurement of } \\
\text { social assistance } \\
\text { programs is } \\
\text { assistance in the } \\
\text { form of money, } \\
\text { goods, or services to } \\
\text { MSMEs who are } \\
\text { vulnerable to the } \\
\text { risk of Covid-19 in } \\
\text { an emergency by } \\
\text { optimizing risk } \\
\text { mitigation that } \\
\text { takes into account } \\
\text { regulatory aspects, } \\
\text { justification, and } \\
\text { supporting data or }\end{array}$} & \multirow[t]{2}{*}{$\begin{array}{l}\text { Risk } \\
\text { mitigation }\end{array}$} & $\begin{array}{l}\text { Need for } \\
\text { MSMEs for } \\
\text { the Social } \\
\text { Assistance } \\
\text { Programs }\end{array}$ & $\begin{array}{l}\text { MSMEs need a Social } \\
\text { Assistance Program } \\
\text { from the Semarang } \\
\text { Government. }\end{array}$ \\
\hline & & & $\begin{array}{l}\text { impact of } \\
\text { social } \\
\text { assistance } \\
\text { programs }\end{array}$ & $\begin{array}{l}\text { The Social } \\
\text { Assistance } \\
\text { Program for } \\
\text { MSMEs can } \\
\text { help MSMEs } \\
\text { face } \\
\text { problems } \\
\text { during the } \\
\text { Covid-19 } \\
\text { pandemic }\end{array}$ \\
\hline
\end{tabular}

Journal of Islamic Accounting and Finance Research - Vol. 3 No. 2 (2021) 
The role of social assistance program on management ...

documentation
based on
procurement
principles and
ethics. Sources
based on (SE3/20
LKPP) \& (Per LKPP
13/2018) consisting
of Pre-Contract
(SE4/20 LKPP) and
Post-Contract (Per
LKPP 9/2018)

documentation

procurement

principles and

ethics. Source

LKPP) \& (Per LKPP

13/2018) consisting

of Pre-Contract

LKPP 9/2018)

$\begin{array}{ll}\begin{array}{l}\text { Distribution } \\ \text { of Social }\end{array} & \begin{array}{l}\text { MSMEs receive direct } \\ \text { cash assistance from the }\end{array} \\ \text { Assistance } & \text { government during the } \\ \text { Programs } & \text { Covid-19 pandemic }\end{array}$

Form of social 1. MSMEs received a assistance working capital program stimulus, either in the form of KUR or other than KUR during the Covid19 pandemic

2. MSMEs received credit relaxation during the Covid19 pandemic.

JIAFR | 301

\section{Results and Discussion}

Based on the above calculation, of a total population of 17,602 MSMEs, the researchers took 144 MSMEs in the food industry sector in Semarang as research samples. Based on the table 2, the number of questionnaires distributed to MSME actors was 238 questionnaires. The questionnaires not meeting criteria 1 (MSMEs operating under 3 years) were 57 questionnaires or 24\%, while questionnaires not meeting criteria 2 (MSMEs not producing during the Covid-19 pandemic) were 37 questionnaires or 16\%. =144 questionnaires were eventually ready to be processed. An overview on 144 questionnaires was summarized in the respondents' self-identity listed in the questionnaires completed by the respondents through online via WhatsApp.

In table 3, it can be seen that MSME business actors with a duration of operation for 3-5 years are 73 respondents or about $51 \%$; $5-10$ years of business are 45 respondents or about $31 \%$; and 26 respondents have been in business for $>10$ years or about $18 \%$. This shows that most respondents have been in business for 3-5 years.

The longer the business, the more the business will develop; and the more the experience and the more knowledge will be possessed by MSME actors, including in financial sector. In addition, the length of business can also 
Mira Fajrin Sholichatun, Hani Werdi Apriyanti

increase their business in the future to have a good perception on the importance of business management through accounting practices. Therefore, through the government's social assistance program in the form of capital/financial assistance, MSMEs can manage the capital/financial assistance through the management accounting practices.

Table 2. Research Samples

\begin{tabular}{lcc}
\hline \multicolumn{1}{c}{ Sampling Criteria } & Number & Percentage (\%) \\
\hline Distributed Questionnaires & 238 & $100 \%$ \\
\hline (-) MSMEs operating under 3 years & 57 & $24 \%$ \\
\hline $\begin{array}{l}\text { (-) MSMEs not producing during the } \\
\text { Covid-19 pandemic }\end{array}$ & 37 & $16 \%$ \\
\hline Questionnaires ready to be processed & 144 & $61 \%$ \\
\hline
\end{tabular}

Source: processed data, 2021

Table 3. Characteristics of Respondents Based on Length of Business Operating

\begin{tabular}{lcc}
\hline \multicolumn{1}{c}{ Length of Business } & Total & Percentage \\
\hline $3-5$ years & 73 & $51 \%$ \\
\hline $5-10$ years & 45 & $31 \%$ \\
\hline$>10$ years & 26 & $18 \%$ \\
\hline Total & 144 & $100 \%$ \\
\hline
\end{tabular}

Source: processed data, 2021

Table 4. Characteristics of Respondents Based on Businesses Still Producing During the Covid19 Pandemic

\begin{tabular}{lcc}
\hline \multicolumn{1}{c}{ Businesses } & Total & Percentage \\
\hline Still producing & 123 & $85 \%$ \\
\hline May produce & 21 & $15 \%$ \\
\hline Total & 144 & $100 \%$ \\
\hline
\end{tabular}

Source: processed data, 2021 
The role of social assistance program on management ...

Table 5. Respondents' Responses to Social Assistance Program Variable

\begin{tabular}{lllllllll}
\hline No. & \multicolumn{1}{c}{ Indicator } & SS & S & N & TS & STS & $\begin{array}{c}\text { Index } \\
\text { (\%) }\end{array}$ & Criteria \\
\hline 1. & $\begin{array}{l}\text { MSMEs needs for } \\
\text { social assistance } \\
\text { program }\end{array}$ & 12.9 & 8.9 & 4.6 & 0.6 & 4.9 & 31.8 & High \\
\hline $\begin{array}{l}\text { Impact of social } \\
\text { assistance programs }\end{array}$ & 10.7 & 11.4 & 7.9 & 0.6 & 4.2 & 34.7 & High \\
\hline 3. & $\begin{array}{l}\text { Distribution of social } \\
\text { assistance programs }\end{array}$ & 7.9 & 9.2 & 10.8 & 6.1 & 11.8 & 45.8 & High \\
\hline 4. & $\begin{array}{l}\text { Form of social } \\
\text { assistance programs }\end{array}$ & 3.9 & 22.4 & 5.4 & 6.1 & 8.0 & 45.8 & High \\
\hline & Average & & & & & 39.5 & High \\
\hline
\end{tabular}

JIAFR | 303

Source: processed data, 2021

Table 6. Respondents' Responses on Management Accounting Practice Variable

\begin{tabular}{llccccccc}
\hline No. & \multicolumn{1}{c}{ Indicator } & SS & S & N & TS & STS & $\begin{array}{c}\text { Index } \\
\text { (\%) }\end{array}$ & Criteria \\
\hline 1. & Financial planning & 3.3 & 9.1 & 11.3 & 6.1 & 6.1 & 35.9 & High \\
\hline 2. & Financial statement & 0.5 & 15.6 & 13.8 & 6.7 & 4.9 & 41.3 & High \\
\hline 3. & $\begin{array}{l}\text { Performance } \\
\text { achievement } \\
\text { evaluation }\end{array}$ & 4.4 & 17.2 & 13.3 & 5.6 & 6.1 & 46.7 & Medium \\
\hline 4. & Decision making & 4.5 & 15.7 & 15.6 & 5.8 & 5.3 & 47.0 & Medium \\
\hline & Average & & & & & $\mathbf{4 2 . 7}$ & High \\
\hline
\end{tabular}

Source: processed data, 2021

According to table 4, business owners as respondents whose businesses are still producing during the Covid-19 pandemic are 123 respondents with a percentage of $85 \%$, then respondents whose businesses may be producing during the Covid-19 pandemic are 21 respondents with presentations. There is a $15 \%$ chance that MSME actors still have plans to continue production during the Covid-19 pandemic. From this, MSME actors during the Covid-19 pandemic are still producing because people prefer to prioritize food needs during the Covid-19 pandemic. So that MSMEs are still trying to maintain their business so that they can still earn income during the Covid-19 pandemic. 
Mira Fajrin Sholichatun, Hani Werdi Apriyanti

Based on the results of respondents' responses, social assistance program had 4 indicators with the average number of social assistance program by 39.5. Thus, it can be concluded that respondents' responses on social assistance program are in high category, meaning that during the Covid-19 pandemic, MSMEs have received the social assistance provided the government.

Based on the results of respondents' responses, management accounting practice had 4 indicators with the average value of 42.7 and categorized into high. So, it can be interpreted that during the Covid-19 pandemic there were several MSMEs that had implemented management accounting practices in their business.

Table 7. Descriptive Statistic

\begin{tabular}{lccccc}
\hline & N & Min & Max & Mean & Std. Deviation \\
\hline $\begin{array}{l}\text { Procurement of Social } \\
\begin{array}{l}\text { Assistance Program } \\
\text { Management Accounting }\end{array}\end{array}$ & 144 & 6 & 22 & 10.19 & 3.907 \\
$\begin{array}{l}\text { Practice } \\
\text { Valid N (listwise) }\end{array}$ & 144 & 7 & 30 & 13.67 & 5.883 \\
\hline
\end{tabular}

Source: processed data, 2021

Table 8. Data Validity Test Results for Social Assistance Program Procurement Variables and Management Accounting Practice Variables

\begin{tabular}{|c|c|c|c|c|}
\hline \multirow[t]{2}{*}{ Variable } & \multirow[t]{2}{*}{ Item } & & & \multirow[t]{2}{*}{ Resul } \\
\hline & & $r$ count & $r$ table & \\
\hline \multirow{5}{*}{$\begin{array}{l}\text { Social Assistance } \\
\text { Program }\end{array}$} & X1.1 & 0.808 & 0.163 & Valid \\
\hline & $\mathrm{X} 1.2$ & 0.684 & 0.163 & Valid \\
\hline & X1.3 & 0.854 & 0.163 & Valid \\
\hline & X1.4 & 0.371 & 0.163 & Valid \\
\hline & X1.5 & 0.741 & 0.163 & Valid \\
\hline \multirow{5}{*}{$\begin{array}{l}\text { Management } \\
\text { Accounting } \\
\text { Practice }\end{array}$} & Y.1 & 0.873 & 0.163 & Valid \\
\hline & Y.2 & 0.930 & 0.163 & Valid \\
\hline & Y.3 & 0.916 & 0.163 & Valid \\
\hline & Y.4 & 0.911 & 0.163 & Valid \\
\hline & Y.5 & 0.879 & 0.163 & Valid \\
\hline
\end{tabular}

Source: processed data, 2021 
The role of social assistance program on management ...

Table 9. Reliability Test Result

\begin{tabular}{lcc}
\multicolumn{1}{c}{ Variable } & Cronbach's Alpha Item & Result \\
\hline $\begin{array}{l}\text { Social Assistance } \\
\text { Program }\end{array}$ & 0.743 & Reliable \\
\hline Management & & Reliable \\
Accounting Practice & 0.955 & \\
\hline
\end{tabular}

Source: processed data, 2021

Table 7 above shows number of respondents (N) as many as 144 respondents. Furthermore, the results of SPSS output above also show that the mean (average) value is greater than the standard deviation, thus indicating that the results of the social assistance program procurement variable and the management accounting practice variable have a fairly good distribution. This is because the standard deviation is a very high, causing the data to show normal results.

Based on table 8 , the results of processed validity test data on social assistance program and management accounting practice, each question item shows that the calculated $r$-count is greater than the r-table saying that the data on both variables are included into valid category.

Table 9 shows that each variable is considered reliable because the value Cronbach's Alpha is more than 0.70 , meaning that social assistance program and management accounting practice are reliable.

Based on the table 10, it can be seen that the value of Asymp number. Sig.(2-tailed) is 0.057. This is in accordance with the requirements of normality test, the sigs value must be $>0.05$. It can be concluded that the processed questionnaire data is normally distributed and can be used for further testing.

Based on table 11, it can be seen that the value of linearity is < alpha $(0.000<0.05)$. Thus, it can be concluded that there is a linear relationship between social assistance programs and management accounting. 
Mira Fajrin Sholichatun, Hani Werdi Apriyanti

Table 10. Normality Test Result

\begin{tabular}{llr}
\hline \multicolumn{2}{c}{ One-Sample Kolmogorov-Smirnov Test } \\
\hline $\mathrm{N}$ & & Unstandardized Residual \\
Normal Parameters & & 144 \\
& Mean & .0000000 \\
Most Extreme Differences & Std. Deviation & 5.26378703 \\
& Absolute & .073 \\
& Positive & .073 \\
Test Statistic & Negative & -.063 \\
Asymp. Sig. (2-tailed) & & .073 \\
\hline
\end{tabular}

Source: processed data, 2021

Table 11. Linearity Test Result

\begin{tabular}{cccccc}
\hline & $\begin{array}{c}\text { Sum of } \\
\text { Squares }\end{array}$ & df & Mean Square & F & Sig \\
\hline Linearity & 870.483 & 1 & 987.834 & 38.240 & .000 \\
\hline
\end{tabular}

Source: processed data, 2021

Table 12. Heteroscedasticity Test Result

\begin{tabular}{|c|c|c|c|c|c|}
\hline \multicolumn{6}{|c|}{ Coefficients $^{\mathrm{a}}$} \\
\hline \multirow[b]{2}{*}{ Model } & \multicolumn{2}{|c|}{$\begin{array}{c}\text { Unstandardized } \\
\text { Coefficients }\end{array}$} & $\begin{array}{l}\text { Standardized } \\
\text { Coefficients }\end{array}$ & \multirow[b]{2}{*}{$\mathrm{t}$} & \multirow[b]{2}{*}{ Sig. } \\
\hline & B & Std. Error & Beta & & \\
\hline 1 (Constant) & 3.066 & .754 & & 4.066 & .000 \\
\hline $\begin{array}{l}\text { Social Assistance } \\
\text { Program }\end{array}$ & .105 & .069 & .126 & 1.514 & .132 \\
\hline
\end{tabular}

Source: processed data, 2021

Table 13. Simple Regression Analysis

\begin{tabular}{|c|c|c|c|c|c|c|}
\hline \multicolumn{7}{|c|}{ Coefficients $^{a}$} \\
\hline \multirow{2}{*}{\multicolumn{2}{|c|}{ Model }} & \multicolumn{2}{|c|}{$\begin{array}{l}\text { Unstandardized } \\
\text { Coefficients }\end{array}$} & \multirow{2}{*}{$\begin{array}{c}\text { Standardized } \\
\text { Coefficients } \\
\text { Beta }\end{array}$} & \multirow[b]{2}{*}{$\mathrm{t}$} & \multirow[b]{2}{*}{ Sig. } \\
\hline & & B & Std. Error & & & \\
\hline 1 & (Constant) & 6.808 & 1.234 & & 5.518 & .000 \\
\hline & $\begin{array}{l}\text { Social Assistance } \\
\text { Program }\end{array}$ & .673 & .113 & .447 & 5.950 & .000 \\
\hline
\end{tabular}

Source: processed data, 2021

Journal of Islamic Accounting and Finance Research - Vol. 3 No. 2 (2021) 
Based on table 12, the Glejser test shows the significance value social assistance program was 0.132 . This is in accordance with the requirements for passing the heteroscedasticity test with the sig value of $>0.05$. Thus, it can be interpreted that this research regression is considered meeting the requirements $(0.132>0.05)$.

JIAFR | 307

Based on the results of the simple regression test above, a simple regression equation can be obtained as follows:

$Y=6.808+0.673 X 1+e$

From the results of the simple regression equation above, it can be explained as follows: 1) The constant value of 6.808 in the regression equation above means that if the value of the independent variable in this case, social assistance program, is zero, then the value of dependent variable or management accounting practice is 6.808. 2) The regression coefficient for social assistance program is 0.673 , meaning that if social assistance program increases by one percent and the other values remain constant, while the management accounting practice will increase by 0.673 . The regression coefficient is indicated by a positive value, meaning that the higher the social assistance program obtained by MSMEs, the higher their level of management accounting practice.

Regression models can be specified with a value of R2 (Adjusted R Square) of 0.194 or $19.4 \%$. This means that management accounting practice during the Covid-19 pandemic can be explained with the value of social assistance program by $19.4 \%$. The remaining value is $80.6 \%(100 \%-19.4 \%$ $=80.4 \%$ ) against the other variables not examined in this study.

The table above shows that results of the calculated $\mathrm{F}$ value is $35.403>$ 3.05 , meaning that the calculated $\mathrm{F}$ value is $>\mathrm{F}$ table and sig. value of 0.000 not more than 0.05 . It is concluded that $\mathrm{H} 1$ is accepted. Thus, social assistance program simultaneously and positively affects management accounting practice. 
Mira Fajrin Sholichatun, Hani Werdi Apriyanti

Table 14. $\mathbf{R}^{2}$ Test Result

Model Summary

\begin{tabular}{|c|c|c|c|c|c|}
\hline \multirow{2}{*}{ JIAFR | 308} & Model & $\mathrm{R}$ & R Square & $\begin{array}{l}\text { Adjusted R } \\
\text { Square } \\
\end{array}$ & Std. Error of the Estimate \\
\hline & 1 & $.447^{a}$ & .200 & .194 & 5.282 \\
\hline
\end{tabular}

Table 15. F Test Result

ANOVA $^{\mathrm{a}}$

\begin{tabular}{|c|c|c|c|c|c|c|}
\hline \multicolumn{2}{|c|}{ Model } & Sum of Squares & $d f$ & Mean Square & $\mathrm{F}$ & Sig. \\
\hline 1 & Regression & 987.834 & 1 & 987.834 & 35.403 & $.000^{\mathrm{b}}$ \\
\hline & Residual & 3962.166 & 142 & 27.903 & & \\
\hline & Total & 4950.000 & 143 & & & \\
\hline
\end{tabular}

Source: processed data, 2021

Table 16. T-test Results

\section{Coefficients $^{\mathrm{a}}$}

\begin{tabular}{lrrrrr}
\hline \multicolumn{7}{c}{$\begin{array}{c}\text { Unstandardized } \\
\text { Coefficients }\end{array}$} & $\begin{array}{c}\text { Standardized } \\
\text { Coefficients } \\
\text { Model }\end{array}$ & $\mathrm{B}$ & Std. Error & Beta & $\mathrm{t}$ & \multicolumn{1}{c}{ Sig. } \\
\hline 1 (Constant) & 6.808 & 1.234 & & 5.518 & .000 \\
& .673 & .113 & .447 & 5.950 & .000 \\
\hline
\end{tabular}

Source: processed data, 2021

The table above shows that the sig value is 0.000 not more than 0.05 . It is concluded that $\mathrm{H} 1$ is accepted. Thus, social assistance program simultaneously and positively affects management accounting practice.

\section{The effect of social assistance program on management accounting practice of}

\section{MSMEs in food industry sector during the Covid-19 pandemic}

Based on the results of descriptive statistical analysis, social assistance program had 4 indicators with the average result of $39.5 \%$ and classified into high category, meaning that during the Covid-19 pandemic, MSMEs have received social assistance programs provided by the government. The results 
of questionnaire proved that $76 \%$ of MSMEs strongly agree and agree, $12 \%$ neutral and $12 \%$ disagree and strongly disagree with 4 indicators. The results of questionnaire also support that almost $85 \%$ of MSMEs still produce during the Covid-19 pandemic, because people prefer to prioritize food needs during the Covid-19 pandemic. Thus, social assistance program provided by the JIAFR | 309 government is utilized by MSMEs properly to maintain their business to continuously earn income during the Covid-19 pandemic.

Furthermore, the results of statistical analysis show that management accounting practice of MSMEs had 4 indicators with the average results of $42.7 \%$ and classified into high category, meaning that MSMEs have developed management accounting practices properly during the Covid-19 pandemic. This is evidenced by the results of questionnaire that $64 \%$ of MSMEs strongly agree, $22 \%$ neutral, and $14 \%$ disagree and strongly disagree.

The average respondent's responses on social assistance program and management accounting practice of MSMEs are classified into high category, respectively by $39.5 \%$ and $42.7 \%$. This is supported by $51 \%$ of MSME actors are in the developing stage because the length of the business is in 3-5-year age group. So, the desire or interest of MSME actors to be productive is still high and easy to get social assistance program from the government during the pandemic Covid-19. Thus, the longer the business, the more the business will develop. The more the experience, the more the knowledge will be possessed by MSME actors, including in financial sector. Length of business is also one requirement to obtain social assistance program from government, such as Authority Credit Program.

Based on the hypothesis results, social assistance program positively affects management accounting practice of MSMEs in food industry sector in Semarang during the COVID-19 pandemic. Thus, the hypothesis is accepted. Meanwhile, the MSME social assistance programs are in the forms of working capital stimulus and credit relaxation. Semarang Government has also provided the Entrepreneurial Credit Program known as Bangkit Jadi Jawara (Kredit Wibawa) as a social assistance program for MSMEs affected by Covid19 in Semarang. In fact, this credit authority program has been expanded 
from offline to online, making it easier for MSME actors to obtain this assistance.

Social assistance program provided by the government is in line with the implementation of policy theory, where Semarang government's social assistance program policy is intended to accelerate the handling of COVID-19 impact on MSMEs. This is proven by $76 \%$ of MSMEs have participated in government policies to accelerate the handling of Covid-19 impact by providing social assistance programs. The social assistance program is well utilized by MSMEs to meet their business needs so that their business can survive and remain sustainable during the Covid-19 pandemic. With the assistance program, MSMEs are encouraged to make decisions. This is in line with the contingency theory. In this case, the contingency of social assistance program is due to the impact of COVID-19, in which MSMEs are eventually able to develop management accounting practice to develop businesses and improve MSME financial management. This is evidenced by 64\% of MSMEs participating in developing management accounting practices during the Covid-19 pandemic, so that the social assistance program can be properly utilized and managed by MSMEs.

The results of this test are in accordance with the research conducted by Sugiri (2020) mentioning that social assistance in intended to survive from the impact of Covid-19 pandemic. In addition, the research conducted by Iping (2020) said that social assistance can also sustainably maintain thepurchasing power of business actor groups so that it can increase business development in the midst of Covid-19 pandemic. Further research conducted by Prajanto \& Pratiwi (2019) shows that good management accounting practice can help management manage the company, including planning and budgeting for decision making in business management. Thus, it can be concluded that the social assistance program provided by the government can be well managed by MSMEs to develop their business in the midst of Covid-19 pandemic by utilizing the management accounting practices. 
The role of social assistance program on management ...

\section{Conclusion}

This study was conducted to determine the effect of procurement of social assistance program on management accounting practice of MSMEs in food industry sector in Semarang during the Covid-19 pandemic. The study was conducted on 238 MSMEs in food industry sector in Semarang with respondents filling out the questionnaires, yet the data processed in this study were only from 144 respondents. The data were processed using SPSS version $25.51 \%$ of MSMEs was in the developing stage because the length of their business was in 3-5-year age group. In addition, 85\% of MSME business actors still produced the products during the COVID-19 pandemic. Based on the respondents' response rate, it can be concluded that MSMEs were aided with the social assistance programs provided by the government.

Based on the results of hypothesis test above, it can be concluded that procurement of social assistance program had a positive effect on management accounting practice of MSMEs in food industry sector during the Covid-19 pandemic. Therefore, the support of government and financial institutions by providing social assistance programs to MSMEs had a positive impact by encouraging MSMEs to implement management accounting practices during the COVID-19 pandemic.

\section{References}

Azudin, Afirah, \& Noorhayati, M. 2018. Management Accounting Practices of SMEs: The Impact of Organizational DNA, Business Potential and Operational Technology. Asia Pacific Management Review, 23(3), 22226.

Helmalia, A. 2018. Pengaruh E-Commerce Terhadap Peningkatan Pendapatan Usaha Mikro Kecil Dan Menengah Di Kota Padang. JEBI (Jurnal Ekonomi dan Bisnis Islam), 3(2), 237.

Herliansyah, Y. 2018. Change of Management Accounting Practices. International Journal of Economics and Business Administration, 6(4), 313. 
Mira Fajrin Sholichatun, Hani Werdi Apriyanti

Iping, B. 2020. Perlindungan Sosial Melalui Kebijakan Program Bantuan Langsung Tnai (BLT) Di Era Pandemi Covid-19: Tinjaun Perspektif Ekonomi Dan Sosial. Jurnal Management Pendidikan dan Ilmu Sosial 1(2). https://dinastirev.org/JMPIS/article/view/290/182.

JIAFR | 312 Lembaga Kebijakan Barang/ Jasa Pemerintah Republik. 2020. Surat Edaran Nomor 4 Tahun 2020. https://jdih.lkpp.go.id/regulation/surat-edarankepala-lkpp/surat-edaran-kepala-lkpp-nomor-4-tahun-2020.

Lembaga Kebijakan Barang/ Jasa Pemerintah Republik Indonesia. 2018a. Peraturan Lembaga Kebijakan Pengadaan Barang/Jasa Pemerintah Nomor 13 Tahun 2018. https://jdih.lkpp.go.id/regulation/peraturanlkpp/peraturan-lkpp-nomor-13-tahun-2018.

Lembaga Kebijakan Barang/Jasa Pemerintahan Republik Indonesia. 2018b. Peraturan Lembaga Kebijakan Pengadaan Barang/Jasa Pemerintah Nomor 9 Tahun 2018. https://jdih.lkpp.go.id/regulation/peraturanlkpp/peraturan-lkpp-nomor-9-tahun-2018.

Lembaga Kebijakan Barang/Jasa Pemerintah Republik Indonesia. 2020. Surat Edaran Nomor 3 Tahun 2020. https://jdih.lkpp.go.id/regulation/suratedaran-kepala-lkpp/surat-edaran-kepala-lkpp-nomor-3-tahun-2020.

Prajanto, A. P., \& Pratiwi, R. D. 2019. Analisis Faktor- Faktor Yang Mempengaruhi Pengelolaan Usaha Kecil Menengah (Studi Kasus Pada Usaha Kecil Dan Menengah Sentra Konveksi Di Klaten). Industrial Revolution 4.0: Design of Financial Accounting System and Transaction Development 10(November), 133-48.

Prihastiwi, Agustina, D., \& Sholihin, M. 2018. Factors Affecting The Use of Management Accounting Practices in Small and Medium Enterprises: Evidence from Indonesia. Jurnal Dinamika Akuntansi, 10(2), 158-76.

Pusung, Rudy, \& Lumowa, S. T. 2015. Analisis Perilaku Biaya Dalam Membuat Keputusan Menerima Atau Menolak Pesanan Khusus Pada Pt. Putra Karangetang. Jurnal Riset Ekonomi, Manajemen, Bisnis dan Akuntansi, 3(1), 24-38.

Rahma, R. 2020. 37,000 SMEs Hiy by COVID-19 Crisis as Goverment Prepares Aid. The Jakarta Post. https://www.thejakartapost.com/news/2020/04/16/37000-smeshit-by-covid-19-crisis-as-government-prepares-aid.html. 
Salle, A. 2019. Penyalahgunaan Bantuan Sosial Di Lingkungan Pemerintah Daerah: Fakta Nyata Dari Laporan Hasil Pemeriksaan Keuangan. Jurnal Kajian Ekonomi \& Keuangan Daerah 4(April), 1-14.

Sugiri, D. 2020. Menyelamatkan Usaha Mikro, Kecil Dan Menengah Dari Dampak Pandemi Covid-19. Fokus Bisnis: Media Pengkajian Manajemen dan Akuntansi, 19(1), 76-86.

Sugiyono. 2018. Alfabeta Bandung Metode Peneiltian Kuantitatif, Kualitatif Dan R\&D.

Suindari, N. M., \& Juniariani, N. M. R. 2020. Pengelolaan Keuangan, Kompetensi Sumber Daya Manusia Dan Strategi Pemasaran Dalam Mengukur Kinerja Usaha Mikro Kecil Menengah (UMKM). KRISNA: Kumpulan Riset Akuntansi, 11(2), 148-54.

Wicaksono, G., \& Nuvriasari, A. 2015. Meningkatkan Kinerja UMKM Industri Kreatif Melalui Pengembangan Kewirausahaan Dan Orientasi Pasar: Kajian Pada Peran Serta Wirausaha Wanita Di Kecamatan Moyudan, Kabupaten Sleman, Propinsi DIY.Jurnal Sosio Humaniora, 3(4), 27-39. 